\title{
PENGEMBANGAN E-MODUL BERBASIS PROJECT BASED LEARNING PADA MATA PELAJARAN SIMULASI DIGITAL UNTUK SISWA KELAS X STUDI KASUS DI SMK NEGERI 2 SINGARAJA
}

\author{
Ni Putu Ayu Wijayanti1), Luh Putu Eka Damayanthi²), I Made Gede Sunarya3), \\ I Made Putrama4) \\ ${ }^{1}$ Fakultas Teknik dan Kejuruan, Universitas Pendidikan Ganesha (penulis 1) \\ email: 1215051003@undiksha.ac.id \\ 2 Fakultas Teknik dan Kejuruan, Universitas Pendidikan Ganesha (penulis 2) \\ email: ekadamayanti@undiksha.ac.id \\ ${ }^{3}$ Fakultas Teknik dan Kejuruan, Universitas Pendidikan Ganesha (penulis 3) \\ email: sunarya@undiksha.ac.id \\ ${ }^{4}$ Fakultas Teknik dan Kejuruan, Universitas Pendidikan Ganesha (penulis 4) \\ email: putrama@undiksha.ac.id
}

\begin{abstract}
Abstrak
Tujuan penelitian ini (1) Untuk mengimplementasikan hasil Pengembangan EModul Berbasis Project Based Learning Pada Mata Pelajaran Simulasi Digital Untuk Siswa Kelas X Studi Kasus Di SMK Negeri 2 Singaraja, (2) Untuk mengetahui respon siswa terhadap Pengembangan E-Modul Berbasis Project Based Learning Pada Mata Pelajaran Simulasi Digital Untuk Siswa Kelas X Studi Kasus Di SMK Negeri 2 Singaraja.

Jenis penelitian yang digunakan dalam penelitian ini adalah Penelitian dan Pengembangan Research and Development $(R \& D)$ dengan model pengembangan $A D D I E$. Subjek penelitian ini yaitu siswa kelas $X$ Tata Boga 5 SMK Negeri 2 Singaraja tahun ajaran 2015/2016. Untuk mengetahui respon siswa terhadap e-modul yang dikembangkan, diperoleh dengan menggunakan metode kuisioner dengan alat pengumpulan data berupa angket.

Hasil analisis respon siswa menunjukkan bahwa persentase siswa yang memberikan respon sangat baik sebesar $60 \%$, persentase siswa yang memberikan respon baik sebesar $40 \%$, dan tidak ada siswa yang memberikan respon cukup, kurang maupun sangat kurang. Berdasarkan hasil penelitian terhadap pengembangan e-modul pada mata pelajaran simulasi digital secara keseluruhan persentase respon siswa menunjukkan angka 90,6 \% dapat dikategorikan sangat baik.
\end{abstract}

Kata kunci: E-Modul, R\&D, ADDIE, Respon, Simulasi Digital.

\section{Abstract}

The purposes of this study were (1) to impelements design of the E-modul development by the Project Based Learning model in the Digital Simulation subject for $X$ grade students of SMK Negeri 2 Singaraja, (2) To know the response of the students toward the E-modul development by the Project Based Learning model in the Digital Simulation subject for $X$ grade students of SMK Negeri 2 Singaraja.

The type of this study was using Research and Development (R\&D) with applied the method ADDIE model. The subject of this study was class of $X$ Tata Boga 5 SMK Negeri 2 Singaraja in study year 2015/2016. The response of the students toward the e-modul development, was obtained by using questionnaire method.

The result of the student's responses were indicated that the percentages were $60 \%$ for the Very Good-response by $40 \%$ of the Good-response. Overall on the result of this study, by the percentage of $90 \%$ can be categorized as Very Good.

Keywords : e-modul, Research and development, ADDIE, response, simulasi digital 


\section{PENDAHULUAN}

Tujuan Pendidikan Nasional di
Indonesia adalah mencerdaskan
kehidupan bangsa dan mengembangkan
manusia Indonesia seutuhnya. Upaya
peningkatan mutu pendidikan di Indonesia
terus-menerus dilakukan oleh pemerintah
Indonesia. Salah satunya adalah
perbaikan dan penyempurnaan kurikulum.
Kurikulum yang diterapkan oleh
pemerintah adalah Kurikulum 2013.
Kurikulum menjadi pedoman yang
digunakan oleh sekolah untuk
mewujudkan pendidikan yang berkualitas. Pendidikan yang berkualitas berawal dari pembelajaran yang berkualitas. Pembelajaran berkualitas dimulai dari pengajar (guru) yang berkualitas dalam menentukan model pembelajaran dan media yang digunakan dalam proses pembelajaran. Melalui model pembelajaran yang inovatif di dalam kelas guru dapat membantu peserta didik mendapatkan informasi, ide, keterampilan, cara berpikir dan mengekspresikan ide (Suprijono,2009).

Berdasarkan pengamatan peneliti di SMK Negeri 2 Singaraja, model pembelajaran yang digunakan pada mata pelajaran Simulasi Digital untuk kelas $X$ adalah model pembelajaran konvensional. Pada proses pembelajaran ini masih ditemui permasalahan yakni rendahnya pemahaman peserta didik dalam penguasaan materi. Berdasarkan wawancara dengan guru mata pelajaran simulasi digital. pada proses pembelajaran ini masih ditemui permasalahan yakni rendahnya pemahaman peserta didik dalam penguasaan materi. Permasalahanpermasalahan yang ditemui adalah (1) Keterbatasan media pembelajaran. Media pembelajaran yang digunakan hanya berupa powerpoint dan buku yang di download dari internet., (2) Guru tidak memiliki referensi lain selain buku yang di download dari internet. Kendalanya adalah buku tersebut sulit untuk didapatkan karena mata pelajaran Simulasi Digital tergolong mata pelajaran yang baru muncul pada kurikulum 2013. (3) Siswa malas untuk belajar dan mencoba, disamping itu siswa juga kurang aktif dan kurang termotivasi karena sumber belajar yang digunakan hanya berupa bahan bacaan atau wacana tanpa ada gambar bergerak atau video. (4) Pemanfaatan internet sekolah belum digunakan secara efektif. Ketika siswa diberikan kesempatan untuk menggali materi di internet dan tidak menemukan materi tersebut, siswa cenderung membuka situs-situs lain yang tidak ada hubungannya dengan pembelajaran. (5) Kurang efektifnya model pembelajaran yang digunakan. . Model pembelajaran yang digunakan saat ini adalah model pembelajaran konvensional. (6) Padatnya materi, sehingga tidak semua materi dapat diajarkan melalui tatap muka di kelas. Terdapat berbagai macam karakteristik siswa SMK Negeri 2 Singaraja khususnya ketika mendapat pelajaran simulasi digital yaitu (1) sebagian besar siswa lebih suka belajar kelompok dibandingkan dengan belajar individu, (2) siswa lebih suka diskusi dengan teman dibandingkan dengan guru, presentase siswa untuk bertanya kepada guru hanya sekitar $10 \%$, (3) sebagian besar siswa lebih suka menggali materi sendiri dibandingkan hanya dengan mendengarkan penjelasan dari guru, karena siswa suka mencoba hal-hal baru, (4) siswa lebih suka belajar dengan menggunakan media pembelajaran yang berisi gambar bergerak dan video dibandingkan dengan hanya berupa wacana.

Menurut Yunita (2013), menekankan bahwa berbagai bentuk media dapat digunakan untuk meningkatkan pengalaman belajar kearah yang lebih konkret, salah satunya yaitu e-modul. Emodul mempunyai kelebihan yaitu sifatnya yang interaktif memudahkan dalam navigasi, memungkinkan menampilkan/memuat gambar, audio, video dan animasi serta dilengkapi tes/kuis formatif yang memungkinkan umpan balik otomatis dengan segera (Suarsana dan Mahayukti, 2013. Penggunaan e-modul harus didukung dengan prasarana alat elektronik semacam komputer, laptop, handphone android, dan sekelasnya. 
SMK Negeri 2 Singaraja khususnya pada mata pelajaran Simulasi Digital telah menerapkan model pembelajaran konvensional, namun berdasarkan permasalahan yang telah diuraikan, model pembelajaran tersebut belum efektif untuk diterapkan. Pembelajaran akan lebih bermakna apabila peserta didik memiliki rasa keingintahuan dan dapat menemukan sendiri pemecahan suatu masalah serta peserta didik dapat meningkatkan peran aktif dalam mengkontruksi pengetahuannya. Berdasarkan uraian tersebut jika dilihat dari permasalahan, karakteristik siswa dan output dari mata pelajaran Simulasi Digital maka perlu di kembangkan e-modul berbasis Project Based Learning. E-modul ini dikembangkan dalam bentuk web dengan menggunakan aplikasi moodle secara online. Pembelajaran menggunakan moodle mengarahkan peserta didik untuk melakukan proses pembelajaran secara mandiri. Selain mengakses materi peserta didik juga dapat mengakses video tutorial dan mengerjakan tugas secara online kapan dan dimana saja tanpa harus mengandalkan waktu jam pelajaran disekolah.

Sedangkan model pembelajaran PjBL cocok untuk diterapkan karena dalam PjBL pebelajar terdorong lebih aktif di dalam belajar mereka, fasilitator berposisi di belakang dan pebelajar berinisiatif, fasilitator memberi kemudahan dan mengevaluasi proyek baik kebermaknaanya maupun penerapannya dalam kehidupan mereka sehari-hari (Santyasa, 2012).

Berkaitan dengan permasalahan yang telah diuraikan di atas, maka peneliti bermaksud mengembangkan e-modul dalam penelitian ini yang berjudul "Pengembangan E-Modul Berbasis Project Based Learning pada Mata Pelajaran Simulasi Digital untuk Siswa Kelas X Studi Kasus di SMK Negeri 2 Singaraja".

\section{Mata Pelajaran Simulasi Digital}

Simulasi digital merupakan salah satu mata pelajaran yang dipelajari oleh siswa kelas $X$ di SMK Negeri 2 Singaraja. Pada pengembangan e-modul ini, akan dimasukkan materi untuk mata pelajaran simulasi digital. Simulasi digital adalah mata pelajaran yang membekali peserta didik agar dapat mengomunikasikan gagasan atau konsep melalui media digital. Dalam proses pembelajaran peserta didik dapat mengomunikasikan gagasan atau konsep yang dikemukakan orang lain dan mewujudkannya melalui presentasi digital. Tujuan akhir setelah peserta didik mempelajari berbagai keteknikan dan cara bekerja yang terkait dengan mata pelajaran kejuruan peserta didik mampu mengomunikasikan gagasan atau konsep yang ditemukannya sendiri atau modifikasi dari gagasan atau konsep yang sudah ada. Ruang lingkup mata pelajaran Simulasi Digital adalah sebagai berikut.

a. Pengelolaan Informasi Digital.

Melalui Pengelolaan Informasi Digital, dimaksudkan untuk memanfaatkan jejaring internet untuk mencari dan mendapatkan informasi sebagai pendukung gagasan atau konsepnya, sekaligus mengomunikasikannya. Sebagai bekal awal memanfaatkan teknologi, diberikan pemahaman dan cara memanfaatkan sarana yang digunakan. Selanjutnya di kuasai cara menggunakan peralatan untuk mempresentasikan dan mengomunikasikan gagasan.

$$
\text { Salah satu cara untuk }
$$

mempresentasikan dan mengomunikasikan gagasan adalah melalui komunikasi daring. Komunikasi daring memungkinkan terjadinya komunikasi dua arah yang dilakukan baik secara sinkron (synchronous), dalam satu waktu yang bersamaan, maupun secara asinkron (asynchronous), dalam waktu yang berbeda. Komunikasi daring dapat dilakukan melalui pengiriman teks dan gambar, bahkan memungkinkan komunikator dan komunikan melakukan percakapan langsung dengan saling melihat gambar mitra bicaranya.

b. Kelas Maya

Melalui kelas maya, dimaksudkan memiliki bekal untuk "belajar kapan saja dan di mana saja". Kelas maya, kelas yang diselenggarakan "jarak jauh" sebagai pelengkap pembelajaran tatap muka, dilaksanakan memanfaatkan jejaring internet. Kelas maya memungkinkan 
peserta didik mengunduh berbagai informasi dan pengetahuan baru yang perlukan, yang telah disediakan oleh guru pengampu kelas maya tersebut, sekaligus dapat menyampaikan tanggapan/jawaban atas pertanyaan guru.

\section{Modul Ajar}

Menurut Winkel (2005), modul merupakan satuan program belajar mengajar yang terkecil, yang dipelajari oleh peserta didik sendiri secara perseorangan atau diajarkan oleh peserta didik kepada dirinya sendiri (selfinstructional) (Winkel, 2005). Modul juga dapat diartikan sebagai sebuah buku yang ditulis dengan tujuan agar peserta didik dapat belajar secara mandiri tanpa atau dengan bimbingan pendidik. Dengan demikian, maka sebuah modul harus dapat dijadikan sebuah bahan ajar sebagai pengganti fungsi pendidik. Kalau pendidik memiliki fungsi menjelaskan sesuatu maka modul harus mampu menjelaskan sesuatu dengan bahasa yang mudah diterima peserta didik sesuai dengan tingkat pengetahuan dan usianya. Modul merupakan alat atau sarana pembelajaran yang berisi materi, metode, batasan-batasan, dan cara mengevaluasi yang dirancang secara sistematis dan menarik untuk mencapai kompetensi yang diharapkan sesuai dengan tingkat kompleksitasnya (Depdiknas, 2008).

\section{E-modul (Modul Elektronik)}

E-modul merupakan tampilan informasi dalam format buku yang disajikan secara elektronik dengan menggunakan hardisk, disket, $\mathrm{CD}$, atau flashdisk dan dapat dibaca dengan menggunakan komputer atau alat pembaca buku elektronik (Wijayanto, 2014). E-modul juga dapat diartikan sebagai alat atau sarana pembelajaran yang berisi materi, metode, batasanbatasan, dan cara mengevaluasi yang dirancang secara sistematis dan menarik untuk mencapai kompetensi yang diharapkan sesuai dengan tingkat kompleksitasnya secara elektronik. Sedangkan menurut Fausih (2015) emodul adalah bahan belajar yang dirancang secara sistematis berdasarkan kurikulum tertentu dan dikemas dalam bentuk satuan waktu tertentu, yang ditampilkan menggunakan piranti elektronik misalnya komputer atau android (Danang, 2015). Dari beberapa pendapat tersebut dapat ditarik kesimpulan bahwa e-modul adalah seperangkat media pengajaran digital atau non cetak yang disusun secara sistematis yang digunakan untuk keperluan belajar mandiri. Sehingga menuntut peserta didik untuk belajar memecahkan masalah dengan caranya sendiri. E-modul mengadaptasi komponen-komponen yang terdapat di dalam modul cetak pada umumnya. Perbedaan hanya pada penyajian fisik emodul yang membutuhkan perangkat komputer untuk menggunakannya.

Tabel 1. Perbandingan E-modul dengan Modul Cetak

\begin{tabular}{|c|c|}
\hline E-Modul & Modul Cetak \\
\hline $\begin{array}{l}\text { Ditampilkan dengan menggunakan } \\
\text { monitor atau layar komputer. }\end{array}$ & $\begin{array}{l}\text { Tampilannya berupa kumpulan kertas } \\
\text { yang berisi informasi tercetak, dijilid, } \\
\text { dan diberi cover. }\end{array}$ \\
\hline $\begin{array}{l}\text { Lebih praktis untuk dibawa kemana- } \\
\text { mana, tidak peduli berapa banyak } \\
\text { modul yang disimpan dan dibawa } \\
\text { tidak akan memberatkan kita dalam } \\
\text { membawanya. }\end{array}$ & $\begin{array}{l}\text { Jika semakin banyak jumlah } \\
\text { halamannya maka akan semakin } \\
\text { tebal dan semakin besar pula } \\
\text { ukurannya, serta semakin berat. Hal } \\
\text { ini akan merepotkan kita dalam } \\
\text { membawanya. }\end{array}$ \\
\hline $\begin{array}{l}\text { Menggunakan CD, USB Flashdisk, } \\
\text { atau memory card sebagai medium } \\
\text { penyimpan datanya. } \\
\text { Biaya produksinya lebih murah } \\
\text { dibandingkan dengan modul cetak. } \\
\text { Tidak diperlukan biava tambahan }\end{array}$ & $\begin{array}{l}\text { Tidak menggunakan CD atau memory } \\
\text { card sebagai medium penyimpan } \\
\text { datanya. } \\
\text { Biaya produksinya jauh lebih mahal, } \\
\text { terlebih lagi jika menggunakan }\end{array}$ \\
\hline
\end{tabular}




\begin{tabular}{l}
\hline E-Modul \\
\hline untuk memperbanyaknya, hanya \\
dengan copy antara user satu \\
dengan lainnya. Pengirirman atau \\
proses distribusi pun bisa dilakukan \\
dengan menggunakan e-mail. \\
Menggunakan sumber daya berupa \\
tenaga listrik dan komputer atau \\
notebook untuk mengoperasikannya. \\
Tahan lama dan tidak lapuk dimakan \\
waktu.
\end{tabular}

Naskahnya dapat disusun secara linear maupun non linear.

Dapat dilengkapi dengan audio dan video dalam satu bundle penyajiannya.

Pada tiap kegiatan belajar dapat diberikan kata kunci atau password yang berguna untuk mengunci kegiatan belajar. Peserta didik harus menguasai satu kegiatan belajar sebelum melanjutkan ke kegiatan belajar selanjutnya. Dengan demikian peserta didik dapat menuntaskan kegiatan belajar secara berjenjang.

\section{Model Pembelajaran Project Based Learning}

Project based learning adalah suatu model atau pendekatan pembelajaran yang membenturkan peserta didik kepada masalah-masalah praktis melalui stimulus dalam belajar (Lindawati, 2012). Pembelajaran berbasis proyek ini peserta didik dilatih untuk (1) bertanggung jawab atas apa yang menjadi tanggung jawabnya, (2) menilai rencana kerja dan bekerja sesuai rencana yang telah dibuat, (3) berkompentensi secara sehat, (4) menerapkan atau mencari penerapan ilmu yang telah dipelajari.

Berdasarkan penjelasan di atas disimpulkan bahwa Project based learning merupakan model pembelajaran yang melatih peserta didik untuk memecahkan masalah sehari-hari dan melatih peserta didik untuk bekerja dalam tim atau kelompok.

Hasil kajian teori hibah pembelajaran memberikan indikasi bahwa, penerapan
PjBL dapat meningkatkan kefektifan pembelajaran. Keefektifan pembelajaran yang dimaksud adalah proses belajar yang diwarnai oleh deepdialogue/artificial thinking dan dalam menghasilkan produkproduk nyata yang berkualitas. Pebelajar memperoleh pengetahuan kritis, kemahiran, pemecahan masalah, strategi belajar mandiri dan keterampilan berpartisipasi dalam kelompok. PjBL menggeser model pembelajaran singkat, terisolasi dan berpusat pada pengajar menuju pada pengintegrasian konsep dengan isu-isu praktik dunia nyata. Menurut Duch (dalam Santyasa, 2012), $\mathrm{PjBL}$ dapat memotivasi pebelajar untuk bertanggung jawab terhadap pekerjaannya dan menantang pebelajar untuk bekerja secara intensif dalam mencari solusi tentang masalah-masalah dunia nyata (Santyasa, 2012).

Karakteristik Model Pembelajaran Project Based Learning.

1. Isi : memuat gagasan yang orisinil 
a. Masalah kompleks

b. Pebelajar menemukan hubungan antar gagasan yang diajukan

c. Pebelajar berhadapan pada masalah yang ill defined

d. Pertanyaan cenderung mempersoalkan masalah dunia nyata

2. Kondisi : mengutaamakan otonomi pebelajar

a. Melakukan inquiry dalam konteks masyarakat

b. Pebelajar mampu mengelola waktu secara efektif dan efisien

c. Pebelajar belajar penuh dengan control diri

d. Mensimulasikan kerja secara professional

3. Aktivitas : investigasi kelompok kolaboratif

a. Pebelajar berinvestigasi selama periode tertentu

b. Pebelajar melakukan pemecahan masalah kompleks
c. Pebelajar
memformulasikan hubungan antar gagasan orisinilnya untuk mengkontruksi keterampilan baru
d. Pebelajar menggunakan teknologi otentik dalam memecahkan masalah
e. Pebelajar melakukan umpan balik mengenai gagasan mereka berdasarkan respon ahli atau dari hasil tes

4. Hasil : produk nyata a. Pebelajar menunjukkan produk
nyata berdasarkan hasil investigasi mereka
b. Pebelajar melakukan evaluasi diri
c. Pebelajar responsif terhadap segala implikasi dari kompetensi yang dimilikinya
d. Pebelajar mendemonstrasikan kompetensi sosial, manajemen pribadi dan regulasi belajarnya.

Tabel 2 Sintaks Model Pembelajaran Project Based Learning (PjBL).

\begin{tabular}{|c|c|c|}
\hline Kegiatan & $\begin{array}{c}\text { Deskripsi Kegiatan/ } \\
\text { Aktivitas Guru }\end{array}$ & Aktivitas Peserta didik \\
\hline $\begin{array}{l}\text { Tahap } 1 \\
\text { (Eksplorasi) } \\
\text { Orientasi Masalah }\end{array}$ & $\begin{array}{lr}\begin{array}{l}\text { Menyampaikan } \\
\text { sesuai }\end{array} & \text { tema } \\
\text { Kompetensi Inti } & \text { dengan }\end{array}$ & $\begin{array}{lr}\text { Mengamati } & \text { atau } \\
\text { menganalisis } & \text { suatu } \\
\text { permasalahan } & \text { yang } \\
\text { diberikan, mengikuti petunjuk } \\
\text { guru. }\end{array}$ \\
\hline $\begin{array}{l}\text { Tahap } 2 \\
\text { Merencanakan } \\
\text { kegiatan kelompok }\end{array}$ & $\begin{array}{l}\text { 1. Mengintruksikan peserta } \\
\text { didik untuk membentuk } \\
\text { kelompok ( } 4-5 \text { orang) }\end{array}$ & $\begin{array}{l}\text { 1. Membentuk kelompok (4- } \\
5 \text { orang), mengikuti } \\
\text { petunjuk guru. }\end{array}$ \\
\hline & $\begin{array}{l}\text { 2. Membimbing peserta didik } \\
\text { mempersiapkan } \\
\text { investigasi } \\
\text { a.Pemilihan topic } \\
\text { b.Membuat peta konsep } \\
\text { atau diagram } \\
\text { c. Membuat rincian } \\
\text { terhadap tahapan } \\
\text { proses } \\
\text { d.Monitoring keria proyek }\end{array}$ & $\begin{array}{l}\text { 2. Merencanakan kegiatan } \\
\text { investigasi } \\
\text { a. Pemilihan topic } \\
\text { b. Membuat peta konsep } \\
\text { atau diagram } \\
\text { c. Pembuatan rincian } \\
\text { terhadap tahapan } \\
\text { proses } \\
\text { d. Monitoring kerja } \\
\text { proyek }\end{array}$ \\
\hline $\begin{array}{l}\text { Tahap } 3 \\
\text { (Elaborasi ) } \\
\text { Melakukan } \\
\text { Investigasi }\end{array}$ & $\begin{array}{lr}\text { Membimbing } & \text { peserta } \\
\text { didik } & \text { melakukan } \\
\text { investigasi } & \end{array}$ & Melakukan investigasi \\
\hline $\begin{array}{l}\text { Tahap } 4 \\
\text { Merencanakan } \\
\text { laporan }\end{array}$ & $\begin{array}{ll}\text { Membimbing } & \text { dan } \\
\text { mengarahkan } & \\
\text { penyusunan laporan } & \end{array}$ & $\begin{array}{l}\text { Menyusun } \\
\text { investigasi }\end{array}$ \\
\hline
\end{tabular}




\begin{tabular}{lll}
$\begin{array}{l}\text { Tahap 5 } \\
\text { (Konfirmasi) }\end{array}$ & $\begin{array}{l}\text { Memfasilitasi kegiatan } \\
\text { presentasi laporan proyek } \\
\text { Presentasi laporan } \\
\text { dan berperan sebagai }\end{array}$ & $\begin{array}{l}\text { Mempresentasikan laporan } \\
\text { kegiatan proyek }\end{array}$ \\
$\begin{array}{l}\text { nahasumber } 6 \\
\text { Evaluasi }\end{array}$ & $\begin{array}{l}\text { Melakukan evaluasi } \\
\text { terhadap laporan hasil } \\
\text { proyek }\end{array}$ & $\begin{array}{l}\text { Mendokumentasikan } \\
\text { masukan-masukan guru yang } \\
\text { berhubungan dengan proyek }\end{array}$ \\
\hline
\end{tabular}

\section{METODE}

Penelitian ini merupakan jenis
penelitian dan pengembangan atau
Research and Development (R\&D).
Research and Development adalah metode penelitian yang digunakan untuk menghasilkan produk tertentu, dan menguji keefektifan produk tersebut (Sugiyono, 2013). Penelitian ini memiliki tujuan untuk mengembangkan e-modul di SMK Negeri 2 Singaraja.

Model pengembangan yang digunakan pada penelitian ini adalah Model ADDIE. Model ini digunakan untuk pengembangan e-modul berbasis project based learning pada mata pelajaran Simulasi Digital. Model ADDIE merupakan model pembelajaran yang bersifat umum dan sesuai digunakan untuk penelitian pengembangan. Ketika digunakan dalam pengembangan, proses ini dianggap berurutan, dimana hasil evaluasi setiap tahap dapat membawa pengembangan pembelajaran ke tahap sebelumnya. Hasil akhir dari suatu tahap merupakan produk awal bagi tahap selanjutnya. Siklus dalam model ADDIE dapat dilihat pada Gambar 1.

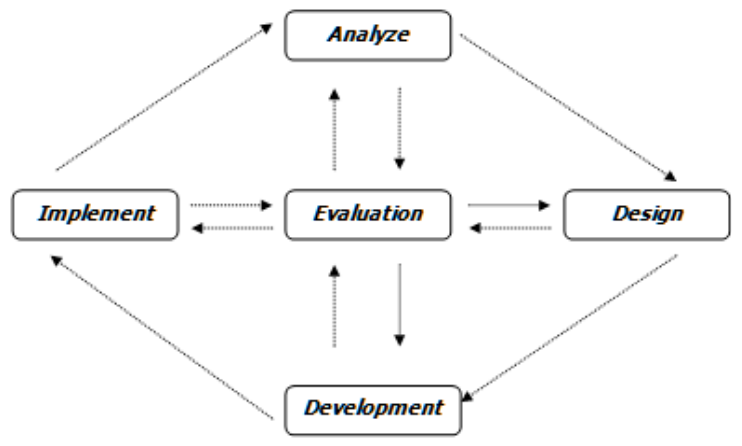

Gambar 1. Siklus Model ADDIE

(Sumber: Adiputra, 2014)

Tahap pertama pada model ADDIE adalah tahap analisis (Analysis). Analisis merupakan suatu tahap untuk mendefinisikan kebutuhan-kebutuhan dalam membangun sistem, khususnya dalam hal ini e-modul Simulasi Digital. Pada tahap ini dilakukan analisis kebutuhan terkait dengan pengembangan e-modul.

Tahap kedua pada model ADDIE adalah tahap desain. Tahap ini juga dikenal dengan istilah membuat rancangan. Pada tahap desain, penulis merancang desain pembelajaran. Pada desain pembelajaran diperoleh desain pengembangan draft modul yang dibagi ke dalam lima kegiatan pembelajaran dengan menggunakan model pembelajaran Project Based Learning.

Tahap ketiga pada model ADDIE adalah tahap pengembangan (development). Pada tahap ini rancangan yang dibuat dari tahap desain akan dikembangkan menjadi e-modul. Pada tahap pengembangan ini dilakukan proses penyusunan materi/bahan ajar, pembuatan video tutorial, penyusunan proyek dan penyusunan soal-soal untuk tes formatif yang akan diimplementasikan ke dalam aplikasi moodle. Dalam proses pengembangan produk ini dibutuhkan perangkat keras dan perangkat lunak.

Tahap keempat pada model ADDIE adalah tahap implementasi (implementation). Pada tahap ini peneliti menguji e-modul yang dikembangkan kepada calon pengguna. Tujuan dilakukannya uji coba ini adalah untuk mengetahui kelayakan produk terhadap proses pembelajaran yang dilaksanakan. Pada tahap uji coba ini dilakukan proses evaluasi terhadap e-modul yang kembangkan. Proses evaluasi ini dilakukan melalui uji coba perorangan, uji coba kelompok kecil dan uji coba lapangan dengan menggunakan angket. Uji coba lapangan dilakukan melalui uji coba kepada siswa kelas $\mathrm{X}$ Program Keahlian Tata Boga 5 SMK Negeri 2 
Singaraja yang berjumlah 25 orang. Selanjutnya uji coba perorangan akan melibatkan 3 orang siswa dari kelas $X$ Tata Boga 5, uji kelompok kecil melibatkan 6 orang siswa di kelas X Tata Boga 5 .

Tahap kelima pada model ADDIE adalah tahap evaluasi. Sejatinya evaluasi bukan bagian yang terpisah tetapi include dimasing-masing proses/bagian pada model ADDIE. (1) Pada tahap analisis dilakukan evaluasi terhadap kebutuhankebutuhan terkait pengembangan produk yaitu e-modul simulasi digital. Evaluasi dilakukan oleh peneliti sendiri dengan bantuan dosen pembimbing. (2) Tahap desain dilakukan evaluasi terkait pengembangan draft modul. Evaluasi ini dilakukan melalui bimbingan kepada dosen pembimbing dan guru mata pelajaran simulasi digital di SMK Negeri 2 Singaraja. (3) Tahap pengembangan dilakukan evaluasi terhadap modul yang sudah diimplementasikan pada aplikasi moodle. Evaluasi ini dilakukan oleh para ahli yaitu ahli isi, ahli desain pembelajaran dan ahli media. (4) Tahap implementasi dilakukan uji coba e-modul simulasi digital kepada pengguna. Proses evaluasi ini dilakukan melalui uji coba perorangan, uji coba kelompok kecil dan uji coba lapangan untuk mengetahui kelayakan produk terhadap proses pembelajaran yang dilaksanakan.

Data yang dikumpulkan untuk dianalisis dalam penelitian ini meliputi informasi sumber belajar, kevalidan emodul serta respon siswa terhadap emodul yang dikembangkan.

Tabel 3. Teknik Pengumpulan Data

\begin{tabular}{|c|c|c|c|c|}
\hline No & Jenis Data & Metode & $\begin{array}{c}\text { Alat } \\
\text { Pengumpulan } \\
\text { Data }\end{array}$ & Sumber Data \\
\hline 1 & $\begin{array}{l}\text { Informasi tentang } \\
\text { sumber belajar }\end{array}$ & Wawancara & Observasi & $\begin{array}{l}\text { Guru Mata Pelajaran } \\
\text { Simulasi Digital di } \\
\text { SMK Negeri } 2 \\
\text { Singaraja }\end{array}$ \\
\hline 2 & $\begin{array}{l}\text { Informasi proses } \\
\text { pembelajaran } \\
\text { simulasi digital }\end{array}$ & Kuisioner & Angket & $\begin{array}{l}\text { Siswa kelas X Tata } \\
\text { Boga } 5\end{array}$ \\
\hline 3 & Kevalidan e-modul & Kuisioner & Angket & $\begin{array}{l}\text { Ahli isi, ahli desain } \\
\text { pembelajaran dan ahli } \\
\text { media }\end{array}$ \\
\hline 4 & $\begin{array}{l}\text { Respon siswa } \\
\text { terhadap e-modul } \\
\text { yang dikembangkan }\end{array}$ & Kuisioner & Angket & $\begin{array}{l}\text { Siswa kelas X Tata } \\
\text { Boga } 5\end{array}$ \\
\hline
\end{tabular}

Metode wawancara yaitu metode yang digunakan untuk menggali informasi tentang sumber belajar yang terdapat di sekolah serta materi yang di ajarkan pada mata pelajaran Simulasi Digital. Disamping itu tujuan dilakukannya wawancara yaitu untuk menggali informasi karakteristik pebelajar tentang ketertarikan siswa terhadap pelajaran Simulasi Digital. Informasi proses pembelajaran digunakan untuk mengetahui bagaimana proses pembelajaran simulasi digital di kelas. Data informasi sumber belajar dan data informasi proses pembelajaran simulasi digital dianalisis secara deskriptif. Angket kevalidan e-modul digunakan pada tahap validasi yang dilakukan oleh para ahli. Angket ini menggunakan skala dua dimana angket untuk ahli isi terdiri dari 20 pernyataan, angket untuk ahli desain pembelajaran terdiri 10 pernyataan dan angket untuk ahli media terdiri dari 15 pernyataan. Selanjutnya data angket dari para ahli akan di analisis secara deskriptif. Angket respon siswa digunakan untuk mengetahui respon siswa terhadap emodul yang dikembangkan. Hasil penilaian uji perorangan, uji kelompok kecil dan respon siswa terhadap e-modul dikonversikan ke dalam skala likert 
dengan lima alternatif jawaban. Pernyaatan untuk angket respon siswa terdiri dari pernyataan positif dan negatif.

Uraian singkat tentang teknik analisis data yang digunakan adalah sebagai berikut.

1. Analisis data kevalidan e-modul bertujuan untuk mengetahui seberapa jauh e-modul yang telah dibuat memenuhi kriteria penilaian dari validator yang ditunjuk. Penilaian ini menggunakan lembar validasi ahli yang selanjutnya menjadi dasar dalam melakukan revisi. Validator yang ditunjuk sebagai ahli isi adalah guru mata pelajaran Simulasi Digital di SMK Negeri 2 Singaraja. Untuk ahli media dan ahli desain pembelajaran adalah Dosen di Jurusan Pendidikan Teknik Informatika. Hasil penilaian dari para ahli dianalisis secara deskriptif. Sedangkan untuk uji perorangan dan kelompok kecil dilakukan oleh siswa kelas $X$ yang pernah mendapatkan mata pelajaran Simulasi digital. Hasil penilaian untuk uji perorangan dan uji kelompok kecil dihitung dengan menggunakan persamaan 1 dan persamaan 2.

2. Analisis data respon siswa dimaksudkan untuk mengetahui bagaimana respon siswa terhadap emodul yang dikembangkan. Respon siswa diambil sample sebanyak 25 orang. Hasil penilaian untuk uji perorangan dan uji kelompok kecil dihitung dengan menggunakan persamaan 1 dan persamaan 2 .

Persentase $=\frac{2 \text { (Jawaban } \times \text { BobotTiap Soal) }}{n \times \text { BobotTertinggi }} \times 100 \% \cdots \cdots$

Untuk presentase keseluruhan subyek dapat dihitung dengan menggunakan persamaan 2.

Persentase $=\frac{\text { Jumlah Presentase Keseluruhan Subyek }}{\text { Banyak Subyek }}$

Hasil penilaian dari uji perorangan, uji kelompok kecil dan respon siswa dikonversikan dengan menggunakan pedoman seperti yang disajikan pada Tabel 4.

Tabel 4. Konversi Tingkat Pencapaian (Sumber : Kirna dan Tegeh, 2012)

\begin{tabular}{lll}
\hline Tingkat Pencapaian & Kualifikasi & Keterangan \\
\hline $90 \%-100 \%$ & Sangat Baik & Tidak perlu direvisi \\
$75 \%-89 \%$ & Baik & Sedikit Direvisi \\
$65 \%-74 \%$ & Cukup & Direvisi Secukupnya \\
$55 \%-64 \%$ & Kurang & Banyak Hal yang Direvisi \\
$0-54 \%$ & Sangat Kurang & Diulang Membuat Produk \\
\hline
\end{tabular}

\section{HASIL DAN PEMBAHASAN}

Pengembangan e-modul mata pelajaran Simulasi Digital dimaksudkan untuk meningkatkan pemahaman siswa dan mempermudah siswa dalam proses belajar baik di rumah maupun disekolah. Dari hasil analisis sumber belajar yang dilakukan, siswa belum menggunakan media pembelajaran berupa e-modul dalam proses pembelajaran. Dengan demikian pengembangan e-modul simulasi digital sangat diperlukan untuk siswa kelas X di SMK Negeri 2 Singaraja.

Tujuan dari pengembangan e-modul simulasi digital adalah untuk membantu siswa dalam memahami materi pembelajaran. Pada pengembangan emodul ini menggunakan model pembelajaran project based learning agar proses pembelajaran tidak hanya berpusat kepada guru melainkan kepada siswa sehingga siswa menjadi lebih aktif dan mandiri.

Tahapan yang dilakukan penulis ketika mengembangkan e-modul disesuaikan dengan tahapan model ADDIE.

Tahap analisis (analysis) meliputi kegiatan analisis modul yaitu analisis terkait dengan kebutuhan-kebutuhan untuk mengembangkan e-modul simulasi digital. 
Tahap kedua adalah perancangan (design) yaitu peneliti melakukan desain pembelajaran yang meliputi penyusunan draft modul yang disesuaikan dengan tahapan-tahapan model pembelajaran project based learning. Tahap ketiga adalah pengembangan (development) yang meliputi kegiatan penyusunan modul, pengembangan e-modul dan integrasi modul ke moodle. Kegiatan penyusunan modul meliputi penyusunan materi/bahan ajar, pembuatan video tutorial, penyusunan proyek dan penyusunan soalsoal untuk tes formatif. Kegiatan pengembangan e-modul meliputi pengembangan rancangan antarmuka, mengatur hak akses pengguna yaitu administrator, guru dan siswa ketika masuk ke halaman mata pelajaran, menyusun tampilan masing-masing pengguna, mengatur tampilan kegiatan pembelajaran, serta menerapkan modul ke sistem e-modul. Sedangkan kegiatan pengembangan integrasi modul ke moodle meliputi penerapan isi dalam modul ke moodle. Pada tahap pengembangan ini juga dilakukan uji oleh para ahli yaitu ahli isi, ahli desain pembelajaran dan ahli media. Tujuan dilakukannya pengujian oleh para ahli ini adalah untuk penyempurnaan e-modul pada mata pelajaran simulasi digital.

Hasil penilaian ahli isi berdasarkan angket sudah dinyatakan "SESUAl", hal tersebut mengindikasikan bahwa materi yang diimplementasikan pada e-modul sudah relevan untuk digunakan dalam pembelajaran simulasi digital. Dari uji ahli isi, terdapat bagian-bagian modul yang masih perlu direvisi. Beberapa masukan dari ahli isi yaitu perlu ditambahkan powerpoint pada masing-masing kegiatan pembelajaran dan tambahkan video tentang sejarah internet pada kegiatan pembelajaran 1 disertakan dengan sumber pengambilan video.

Hasil penilaian ahli desain pembelajaran berdasarkan angket sudah dinyatakan "SESUAl", hal tersebut mengindikasikan bahwa penerapan model pembelajaran project based learning dalam e-modul sudah sesuai, namun terdapat beberapa masukan dari ahli desain seperti tambahkan rubrik untuk penilaian sikap, project dan tes formatif, tambahkan manual book e-modul untuk guru dan siswa, tahapan model project based learning agar bisa disesuaikan dengan materi pembelajaran dan evaluasi harus dilaksanakan per tahapan.

Hasil penilaian ahli media berdasarkan angket sudah dinyatakan "SESUAI". Dari evaluasi ahli media, ada beberapa masukan yang diberikan seperti penulisan daftar pustaka untuk materi dan gambar agar di diuraikan dengan menggunakan resource label, dan siswa tidak perlu men-download, perjelas lagi untuk video tutorial seperti penambahan suara atau teks pada setiap langkahnya agar siswa mudah mengikuti video tutorial yang disediakan, dan perjelas warna tulisan untuk menu dan linknya agar mudah dilihat.

Tahap keempat yaitu implementasi. Tahap ini meliputi uji perorangan, uji kelompok kecil dan uji lapangan (respon siswa).

Uji perorangan dilakukan terhadap 3 orang siswa dari kelas $X$ Tata Boga 5 . Berdasarkan angket yang disebarkan, hasil penilaian atau tanggapan yang diminta adalah memberikan skor 1 sampai 5 pada masing-masing pernyataan. Persentase untuk uji coba perorangan diperoleh hasil yaitu sebagai berikut.

Persentase $=\frac{\text { Jumlah Presentase Keseluruhan Subyek }}{\text { Banyak Subyek }}$
Persentase $=\frac{1767}{20}=88,3 \%$

Persentase tingkat pencapaian isi e-modul yaitu $88,3 \%$ berada pada kualifiasi baik. Jika dilihat dari hasil pencapaian, masih terdapat $11,7 \%$ perlu dilakukan revisi. Peneliti melakukan revisi melalui masukan dan saran dari masing-masing responden. 
Tabel 5. Rekapitulasi Penilaian pada Uji Perorangan

\begin{tabular}{lcc}
\hline $\begin{array}{l}\text { Konversi tingkat } \\
\text { pencapaian }\end{array}$ & Persentase (\%) & $\begin{array}{c}\text { Jumlah Responden } \\
\text { (orang) }\end{array}$ \\
\hline Sangat Baik & $33,3 \%$ & 1 \\
Baik & $66,7 \%$ & 2 \\
Cukup & $0 \%$ & 0 \\
Kurang & $0 \%$ & 0 \\
Sangat Kurang & $0 \%$ & 0 \\
\hline
\end{tabular}

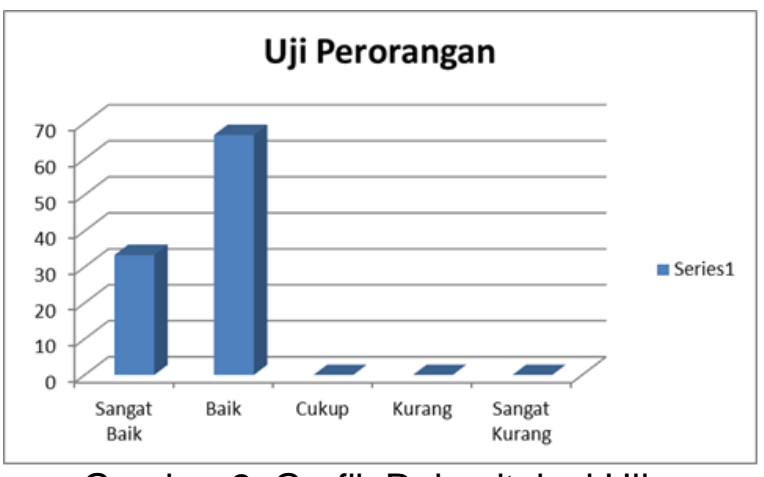

Gambar 2. Grafik Rekapitulasi Uji Perorangan

Berdasarkan rekapitulasi penilaian dari masing-masing responden, memperlihatkan bahwa penilaian yang diberikan oleh siswa adalah sangat baik $33,3 \%$, baik $66,7 \%$, cukup $0 \%$, kurang $0 \%$, dan sangat kurang $0 \%$, dimana masing-masing jumlah responden yang memberikan tanggapan sangat baik adalah satu orang dan tanggapan baik berjumlah dua orang. Adapun pemaparan beberapa masukan yang telah dirangkum oleh peneliti sebagai dasar untuk melakukan revisi adalah e-modul yang diterapkan sudah cukup bagus dan mudah dipahami. Materi yang diimplementasikan pada e-modul sudah dipaparkan tahap demi tahap serta dilengkapi dengan video tutorial. Terdapat beberapa kesalahan seperti kesalahan ketik, kesalahan penggunaan huruf kecil dan kapital serta kesalahan penggunaan tanda baca. Peneliti sudah memperbaikinya berdasarkan komentar dari masingmasing responden. Kendala yang dihadapi oleh peneliti ketika melakukan uji coba perorangan yaitu terdapat salah satu orang siswa yang belum mengerti beberapa langkah-langkah ketika menggunakan e-modul. Peneliti mengarahkan siswa tersebut untuk membaca tutorial pengguna yang sudah terdapat pada e-modul dan mengajarkannya tentang cara penggunaan e-modul.

Setelah uji perorangan selesai dan direvisi, maka dilanjutkan dengan uji kelompok kecil. Uji kelompok kecil dilakukan oleh 6 orang siswa kelas $X$ Tata Boga 5. Pada uji coba kelompok kecil terhadap e-modul simulasi digital hasil penilaian yang diminta adalah memberikan skor 1 sampai 5 pada masing-masing penilaian. Persentase untuk uji coba kelompok kecil diperoleh hasil yaitu sebagai berikut.

Persentase $=\frac{\text { Jumlah } \text { Presentase Keseluruhan Subyek }}{\text { Banyak Subyek }}$
Persentase $=\frac{1803}{20}=90,2 \%$

Persentase tingkat pencapaian isi e-modul yaitu 90,2 \% berada pada kualifikasi sangat baik. 
Tabel 6. Rekapitulasi Penilaian Pada Uji Kelompok Kecil

\begin{tabular}{lcc}
\hline $\begin{array}{l}\text { Konversi } \\
\text { Tingkat } \\
\text { Pencapaian }\end{array}$ & $\begin{array}{c}\text { Persentase } \\
\text { (\%) }\end{array}$ & $\begin{array}{c}\text { Jumlah Responden } \\
\text { (orang) }\end{array}$ \\
\hline Sangat Baik & $66,7 \%$ & 4 \\
Baik & $33,3 \%$ & 2 \\
Cukup & $0 \%$ & 0 \\
Kurang & $0 \%$ & 0 \\
Sangat Kurang & $0 \%$ & 0 \\
\hline
\end{tabular}

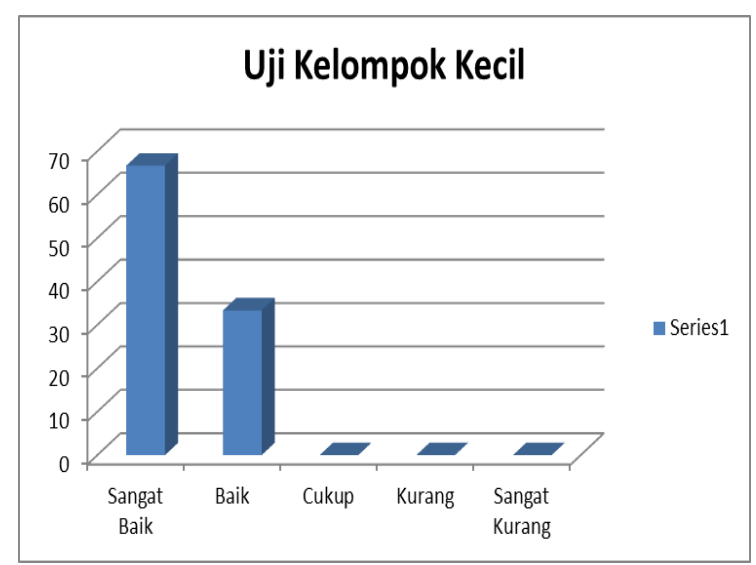

Gambar 3. Grafik Rekapitulasi Uji Kelompok Kecil

Berdasarkan rekapitulasi penilaian dari masing-masing responden, memperlihatkan bahwa penilaian yang diberikan oleh siswa adalah sangat baik $66,7 \%$, baik 33,3\%, cukup 0\%, kurang $0 \%$, dan sangat kurang $0 \%$, dimana masing-masing jumlah responden yang memberikan tanggapan sangat baik adalah empat orang dan tanggapan baik berjumlah dua orang. Tidak ada revisi untuk uji kelompok kecil. Kendala yang dihadapi peneliti ketika melakukan uji kelompok kecil sama halnya dengan uji coba perorangan yaitu terdapat beberapa siswa yang belum mengerti beberapa langkah-langkah ketika menggunakan emodul. Peneliti mengarahkan siswa tersebut untuk membaca tutorial pengguna yang sudah terdapat pada emodul dan mengajarkannya tentang cara penggunaan e-modul.

Setelah uji coba kelompok kecil selesai dilanjutkan dengan uji coba lapangan (respon siswa).

Pada uji coba lapangan terhadap e-modul simulasi digital hasil penilaian yang diminta adalah memberikan skor 1 sampai 5 pada masing-masing penilaian. Persentase untuk uji coba lapangan diperoleh hasil yaitu sebagai berikut.

$$
\begin{aligned}
& \text { Persentase }=\frac{\text { Jumlah Presentase Keseluruhan Subyek }}{\text { Banyak Subyek }} \\
& \text { Persentase }=\frac{1358}{15}=90,6 \%
\end{aligned}
$$

Persentase tingkat pencapaian isi e-modul yaitu 90,6 \% berada pada kualifikasi sangat baik. Rata-rata responden memberikan skor 4 dan 5 . Tidak ada responden yang memberikan skor 3, 2, 1 ataupun 0 .

Tabel 7. Rekapitulasi Penilaian pada Uji Lapangan

\begin{tabular}{lcc}
\hline $\begin{array}{l}\text { Konversi tingkat } \\
\text { pencapaian }\end{array}$ & $\begin{array}{c}\text { Persentase } \\
\text { (\%) }\end{array}$ & $\begin{array}{c}\text { Jumlah Responden } \\
\text { (orang) }\end{array}$ \\
\hline Sangat Baik & $60 \%$ & 15 \\
Baik & $40 \%$ & 10 \\
Cukup & $0 \%$ & 0 \\
Kurang & $0 \%$ & 0
\end{tabular}




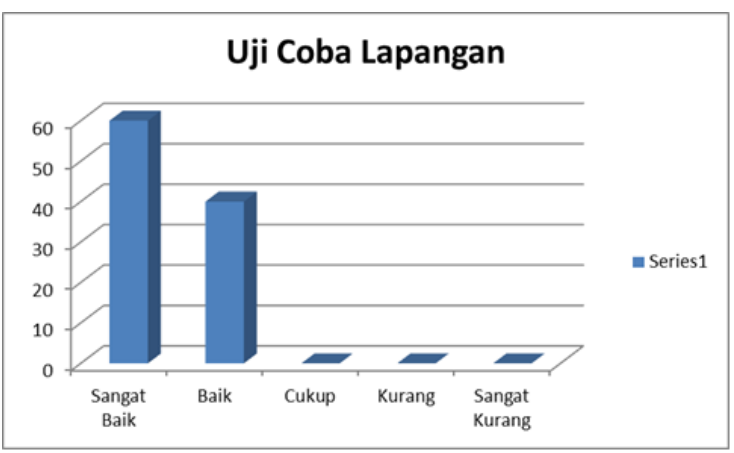

Gambar 4. Grafik Rekapitulasi Uji Lap.

Pada

pengujian

ini diimplementasikan kegiatan pembelajaran 1 yaitu materi tentang pengenalan internet. Uji respon siswa ini dilakukan oleh 25 orang siswa dari kelas X Tata Boga 5. Selama pembelajaran berlangsung siswa terlihat antusias, mandiri dan aktif mengikuti proses pembelajaran dengan menggunakan emodul simulasi digital. Siswa memperhatikan peneliti ketika mengajar di kelas dan mengikuti proses pembelajaran dengan baik. Terdapat beberapa siswa yang mengajukan pertanyaan ketika ada hal-hal yang belum dipahami baik itu terkait dengan materi maupun tata cara penggunaan e-modul. Seperti halnya cara meng-upload tugas dan men-download materi pelajaran. Peneliti mengajar sesuai dengan tahapan-tahapan model pembelajaran project based learning. Setelah proses pembelajaran selesai, peneliti menyebarkan angket respon kepada siswa mengenai pembelajaran dengan menggunakan e-modul simulasi digital. Berdasarkan rekapitulasi penilaian dari masing-masing responden, memperlihatkan bahwa penilaian yang diberikan oleh siswa adalah sangat baik $60 \%$, baik $40 \%$, cukup $0 \%$, kurang $0 \%$, dan sangat kurang $0 \%$, dimana masingmasing jumlah responden yang memberikan tanggapan sangat baik adalah lima belas orang dan tanggapan baik berjumlah sepuluh orang.

Kendala yang dihadapi peneliti ketika melakukan uji respon siswa yaitu terkait masalah teknis, dimana pada saat melakukan implementasi terdapat beberapa komputer yang tidak dapat dioperasikan. Dengan demikian siswa secara berkelompok menggunakan komputer agar dapat mengakses e-modul simulasi digital selama proses pembelajaran berlangsung. Secara umum proses pembelajaran dapat dilaksanakan dengan baik.

Berdasarkan pembahasan diatas, secara garis besar pengembangan emodul simulasi digital layak untuk digunakan. Hal ini dibuktikan dengan pernyataan siswa yaitu penerapan emodul simulasi digital sangat mendukung proses pembelajaran, e-modul simulasi digital memudahkan siswa untuk mencari informasi terkait materi pelajaran, dan emodul ini memotivasi siswa untuk belajar. Berdasarkan penilaian-penilaian yang dilakukan oleh ahli isi, ahli desain pembelajaran, ahli media, uji coba perorangan, uji coba kelompok kecil dan uji lapangan (respon siswa), dapat disimpulkan bahwa e-modul simulasi digital berbasis project based learning layak digunakan sebagai sumber belajar untuk siswa kelas $X$ di SMK Negeri 2 Singaraja. Melalui penerapan e-modul simulasi digital ini diharapkan mampu membantu guru yang bersangkutan selama proses pembelajaran dan diharapkan siswa dapat belajar secara aktif dan mandiri baik di sekolah maupun di rumah dengan memanfaatkan e-modul ini. Disamping itu, dengan pemanfaatan emodul ini diharapkan intensitas belajar siswa pada mata pelajaran simulasi digital meningkat.

\section{SIMPULAN DAN SARAN}

Berdasakan hasil penelitian dan pembahasan pada penelitian pengembangan e-modul berbasis project based learning pada mata pelajaran simulasi digital, maka penulis dapat menarik kesimpulan sebagai berikut.

1. Implementasi e-modul simulasi digital berbasis project based learning sudah dinyatakan baik. Hal ini dapat dilihat 
dari rata-rata persentase berdasarkan hasil pengujian yang dilakukan. Secara umum siswa terlihat antusias dan terlibat aktif selama proses pembelajaran berlangsung.

2. Berdasarkan respon siswa terhadap pengembangan e-modul berbasis project based learning pada mata pelajaran simulasi digital di SMK Negeri 2 Singaraja didapatkan ratarata persentase keseluruhan subyek sebesar 90,6\%. Jika dikonversikan kedalam tabel konversi termasuk dalam kategori "sangat baik".

Beberapa hal yang dapat disampaikan sebagai bahan pertimbangan lebih lanjut yaitu:

1. E-modul simulasi digital di SMK Negeri 2 Singaraja yang dikembangkan hanya sampai pada tahap pengujian untuk memperoleh respon siswa dan belum sampai pada pengukuran hasil belajar akhir siswa dengan menggunakan e-modul. Oleh karena itu, terbuka bagi para peneliti lain untuk mengkaji lebih jauh pengukuran hasil belajar akhir siswa menggunakan e-modul ini.

2. Bagi pengembang selanjutnya dapat mengembangkan modul dengan mata pelajaran lain selain mata pelajaran simulasi digital seperti tata hidang

3. Bagi pengembang selanjutnya yang mengembangkan modul, disarankan modul tersebut dapat dioperasikan dengan baik pada browser selain Google Chrome dan Mozilla Forefox.

\section{DAFTAR PUSTAKA}

Suprijono, Agus. 2009. Cooperative Learning: Teori dan Aplikasi Paikem. Bandung: Pustaka Pelajar.

Suarsana dan Mahayukti. 2013. Pengembangan E-Modul Berorientasi Pemecahan Masalah Untuk Meningkatkan Keterampilan Berpikir Kritis Mahapeserta didik. Jurnal Pendidikan Indonesia Vol 2 No. 2, 264-275.

Santyasa. 2012. Pembelajaran inovatif. Singaraja.
Winkel. 2005. Psikologo Pengajaran. Yogyakarta: Media Abadi.

Depdiknas. 2008. Penulisan Modul. 2008: Direktorat Jendral Peningkatan Mutu dan Tenaga.

Wijayanto. 2014. Pengembangan E-Modul Berbasis Flip Book Maker Dengan Model Project Based Learning Untuk Mengembangkan Kemampuan Pemecahan Masalah Matematika. Pendidikan Matematika, 625-628.

Danang, Fausih. 2015. Pengembangan Media E-Modul Mata Pelajaran Produktif Pokok Bahasan "Instalasi Jaringan Lan (Local Area Network)" Untuk Peserta didik Kelas XI Jurusan Teknik Komputer Jaringan Di Smk Nengeri 1 Labangbangkalan Madura. Teknologi Pendidikan, 1-9.

Lindawati, Fatmariyanti dkk. 2012. Penerapan Model Pembelajaran Project Based Learning Untuk Meningkatkan Kreativitas Peserta didik Man 1 Kebumen. Pendidikan dan IImu Keguruan Vol.3, No.1, 4245.

Sugiyono. 2013. Metode Penelitian Pendidikan Pendekatam Kuantitatif, Kualitatif, dan R\&D. Bandung: Alfabeta.

Adiputra. 2014. Pengembangan E-Modul pada Materi "Melakukan Instalasi Sistem Operasi Jaringan Berbasis GUI dan Text" untuk Peserta didik Kelas X Teknik Komputer dan Jaringan SMK Negeri 3 Singaraja . Karmapati Vol. 3, No. 1, 19-25.

Kirna dan Tegeh. 2012. Pengembangan Bahan Ajar Metode Penelitian Pendidikan Dengan Addie Model. 12-26. 